\title{
The effect of colony relocation on loss and disorientation of honeybees
}

\author{
D.L. Nelson ${ }^{1}$ and S.C. Jay ${ }^{2}$
}

1 Agriculture Canada Research Station, Box 29, Beaverlodge, Alberta, Canada TOH OCO, and

2 Department of Entomology, University of Manitoba, Winnipeg, Manitoba, Canada R3T 2N2

(received 11 January 1988, accepted 23 January 1989)

Summary - The effects of colony relocation on bee loss and disorientation were studied at Beaverlodge, Alberta, Canada. Bee loss was $22 \%$ for unmoved colonies over a 7 day period, $32 \%$ for colonies transported at least $14 \mathrm{~km}$, but returned to the original site and $45 \%$ for colonies that were moved at least $14 \mathrm{~km}$ to a new apiary site. Significant treatment and day effects were evident. Drifting was greatest in the colonies that were moved (38\%) to a new apiary site and least in the colonies that were unmoved (13\%). The rate of bee loss and drift were highest during the first day of flight, but continued at a decreased rate for the next 6 days.

\section{Apls mellifera - orientation - drifting - moving of colonles}

Résumé - Influence du déplacement des colonies sur la perte et la désorientation des abeilles (Apis mellifica). On a utilisé des groupes d'abeilles marquées pour déterminer la perte et la dérive des abeilles dans les situations suivantes : $A$, colonie non déplacée; $B$, colonie déplacéo à, au moins $14 \mathrm{~km}$, puis remise dans son rucher d'origine; $C$, colonie déplacée à, au moins $14 \mathrm{~km}$ dans un nouveau rucher. Les expériences ont été menées près de Beaverlodge, dans l'Alberta, Canada (lat. $55^{\circ} 10^{\prime} \mathrm{N}$ ) avant les principales miellées. Dans chaque traitement, les colonies étaient placées en ligne droite avec leur entrée décalée et la acolonie marqueusen située au centre (Figs. 1 et 2). Les colonies ont été déplacées le soir, une fois l'activité des abeilles cessée. On a déterminé la perte et la dérive, en dénombrant dans chaque ruche les abeilles marquées au bout de 1, 4 et 7 jours d'activité, le matin avant que les abeilles ne s'envolent. Une analyse de la déviance du nombre d'abeilles perdues montre des effets significatifs du traitement, du jour et de l'action combinée traitement et du jour (Tableau I). La perte en abeilles a été de $22 \%$ sur une période de 7 jours pour les colonies non déplacées (traitement A), de 32\% pour les colonies du traitement $B$ et de $45 \%$ pour celles du traitement $C$. Le Tableau III donne la probabilité estimée des pertes d'abeilles. Les colonies ont également subi une forte dérive au cours de l'expérience. C'est dans le traitement $C$ qu'elle a été la plus forte (38\%) et dans le traitement A la moins forte (13\%).

Apls mellifica - orlentation - dérlve - déplacement de colonies

Zusammenfassung - Effekte der Umsiediung elnes Blenenvolkes auf den Verlust und die Desorientierung der Honigbienen. Gruppen von markierten Bienen wurden untersucht, um Verlust und Verflug von Bienen in Völkem unter folgenden Bedingungen zu studieren : 
A) Nicht bewegt (unmoved)

B) mindestens $14 \mathrm{~km}$ bewegt, aber an den ursprünglichen Ort zurückgebracht (transported), und

C) an einen mindestens $14 \mathrm{~km}$ entfernten neuen Ort gebracht (relocated).

Die Experimente wurden in der Nähe von Beaverlodge, Alberta, Kanada (lat. 55 $10^{\circ} \mathrm{N}$ ), vor dem HauptnektarflüB durchgeführt. Die drei Gruppen wurden in Linien mit versetzten Eingängen (Abb. 1) angeordnet, das "Markervolk" befindet sich in der Mitte und zwei leere Völker an jeder Seite. Für die Untersuchung des Verflugs wurde die umgekehrte Anordnung gewählt : ein leeres Volk in der Mitte und zwei «Fängervölker», die die verflogenen Bienen aufnehmen, zu jeder Seite (Abb. 2). Die Völker wurden abends nach dem Bienenflug bewegt. Verlust und Verflug wurden durch Auszählen von markierten Bienen in jedem Volk am Morgen vor dem Bienenflug nach 1, 4 und 7 Tagen bestimmt. Eine Analyse der Abweichungen von der zu enwartenden Binomialverteilung im Verlust an Bienen zeigte signifikante Effekte der Behandlung, des Tages und der Behandlung $\times$ Tag (Tabelle 1). Der Bienenverlust war bei den nicht bewegten Völkern nach 7 Tagen 22\%, bei den mindestens $14 \mathrm{~km}$ transportierten $32 \%$ und bei den an einen neuen Ort umlogierten $45 \%$. In Tabelle III findet man die geschätzte Wahrscheinlichkeit für Bienenverluste. Die Bienen verflogen sich auch sehr stark während des Experiments. Der Verflug war bei Experiment $C$ am stärksten (38\%) und am geringsten bei Experiment $A(13 \%)$.

Apis mellifera - Orientierung - Bienenverflug - Umsiedlung

\section{Introduction}

The moving of colonies to new apiary sites, with the associated risk of loss and drifting of bees has increased on the Canadian prairies. Loss and drifting of worker honeybees has been studied in established apiary sites (e.g., Free, 1958; Free and Spencer-Booth, 1961; Jay, $1965,1968)$, in recently installed package colonies (e.g., Jay, 1969, 1970) and in colonies moved outdoors after having been wintered indoors (Jay and Harris, 1979). Less is known about loss and drifting of bees when colonies are moved during the summer, with the exception of colonies moved for pollination purposes (e.g., Free et al., 1960; Todd and McGregor, 1960; Moeller, 1973; Free and Williams, 1974). In this study, we investigated the loss and drifting of honey bees when colonies are moved.

\section{Materials and Methods}

Replicated (3) experiments were conducted between 18-30 June 1983 near Beaverlodge,
Alberta, Canada (lat. $55^{\circ} 10^{\prime} \mathrm{N}$ ) before the major nectar flow occurred. Langstroth colonies (single-chambered) were used, each containing 6-7 frames of honeybees (Apis mellifera L.) headed by California queens. Cohorts of marked bees were used to study the loss and drift that resulted during the experiment. Newly emerged bees (less than $24 \mathrm{~h}$ old) were obtained by selecting and incubating $\left(32^{\circ} \mathrm{C}\right)$ brood combs. Bees were marked with a paintfilled syringe (Harris, 1979) and transferred to queenright colonies. These colonies were designated as 'marker colonies' and were kept in isolation until used in the experiment.

Loss and drifting of worker bees were measured under 3 situations in which the colonies were : A, not moved (unmoved); $B$, moved at least $14 \mathrm{~km}$ but returned to the original apiary site (transported); and C, moved at least $14 \mathrm{~km}$ to a new apiary site (relocated). At least 5 days prior to movement, colonies representing each of the 3 treatments were arranged in a straightline with off-set entrances (Fig. 1) with the 'marker colony' in the center position with two 'empty colonies' (hive body, cover and bottom board but without frames and bees) on each side of the marker colony. The 'unmoved' and 'transported' colonies were setup in one apiary (apiary 2) and the 'relocated' colonies were setup in another apiary (apiary 1). Similarly, for each treatment, but in the opposite apiary site, layouts were setup with an 'empty colony' in the central location and two 'catcher colonies' (colonies 
with bees used to retain drifting bees) on each side (see Fig. 2 for an example of the set-up and move of treatment $C$ ).

Colonies were moved in the evening (20:00-23:00 h) after bee flight had ceased. Empty colonies in treatments $A$ and $B$ of apiary 2 were replaced by catcher colonies from apiary 1 , each being placed in their respective positions in the layout. The marker colony from apiary 1 (treatment C) was moved to apiary 2 and put in place of the one centrally located empty colony; the marker colony in apiary 2 (treatment B) was transported for at least 14 $\mathrm{km}$ and then returned to its original position. Thus all colonies were in the same apiary site during the experimental period.

Prior to the initiation of bee flight of the morning following the move, marked bees in each marker colony were counted. Similarly, on days 1,4 and 7 after the initiation of each experiment, all colonies were inspected for marked bees.

\section{Data calculation}

Bee loss and drift were calculated for each examination period by subtracting the marked bees present from the previous count. In this way, the number and percent of lost and drifting bees were calculated for each examination period.

Since the number of lost bees was calculated from the number present, these values have a binomial distribution. Consequently, a series of generalized linear models assuming a binomial error distribution (McCullagh and Nelder, 1983) were used to evaluate the effects of replicates, days and treatments. The goodness of fit was measured
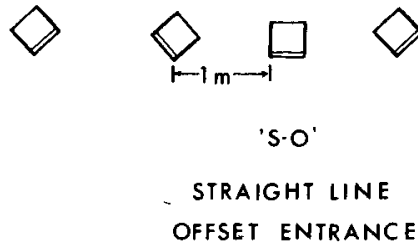

Fig. 1. Colonies were placed in a straightline, offset entrance layout ( $S-O)$ facing in a southerly direction. by the deviance, i.e., twice the negative of the $\log$ likelihood. Differences in the deviance and degrees of freedom were compared with the chi-square distribution to determine the significance of the various factors. All computations were performed using GENSTAT, release 4.04, including the supplied macrolibrary.

\section{Results and Discussion}

\section{Loss of bees}

The number of bees lost from the marker colonies was significantly affected by day, treatment and the treatment $X$ day interaction (Table I). The number of bees lost varied significantly from one inspection period to the next but there were no apparent trends. The rate of bee loss was greatest after one day of bee flight. Rates of loss were lower for counts after 4 and 7 days of flight (Table II).

\begin{tabular}{|c|c|c|c|c|c|}
\hline \multicolumn{6}{|c|}{$\ln m \rightarrow 1$} \\
\hline APIARY 1 & 0 & 0 & M & 0 & 0 \\
\hline APIARY & $x$ & $x$ & 0 & $x$ & $x$ \\
\hline FINAL & $x$ & $x$ & $M$ & $x$ & $\mathbf{x}$ \\
\hline
\end{tabular}

Fig. 2. "Empty colonies" (O, hive body, bottom board and cover but without frames and bees); "catcher colonies" (X, colonies with bees used to retain drifting bees) and "marker colonies" ( $M$, colonies that contain marked bees) were used to setup apiary sites for the experiments. This figure is an example for treatment (C) where the marker colony was setup in apiary 1 with 2 empty colonies on each side. When the experiment started, (M) was moved to apiary 2 and placed between the catcher colonies. The use of empty colonies allows for bees in a marker colony to orient to an arrangement but not to drift into those colonies. 
Table I. Analysis of deviance for the number of bees lost.

\begin{tabular}{llc}
\hline $\begin{array}{l}\text { Additional terms } \\
\text { in model }\end{array}$ & $\begin{array}{l}\text { Change } \\
\text { in df. }\end{array}$ & $\begin{array}{l}\text { Change } \\
\text { in deviance }\end{array}$ \\
\hline Replication (R) & 2 & $2.79 \mathrm{NS}$ \\
Days (D) & 2 & $39.51 * *$ \\
R X D & 4 & $2.21 \mathrm{NS}$ \\
Treatment (T) & 2 & $27.79 *$ \\
TxR & 4 & $1.84 \mathrm{NS}$ \\
TXD & 4 & $10.11 *$ \\
\hline
\end{tabular}

- $P<0.05, " * P<0.01$ as determined by chi-square.

Losses in the number of bees, averaged across time (days) of inspection, were greatest when the colonies were relocated (a total of $45 \%$ ). Losses were less from colonies transported (32\%) but returned to their original site or from colonies that were unmoved $(22 \%)$ than from relocated colonies. The estimated probability of bee loss is given in Table III.

Previous studies (Jay, 1969; 1970) have shown that bee losses can range as high as $25-40 \%$ from package bees

Table II. Mean number of bees lost and drifting from colonies that were not moved (treatment A), transported $14 \mathrm{~km}$ and returned to their original location (treatment B), or transported for $14 \mathrm{~km}$ from one apiary site to another (treatment $\mathrm{C}$ ).

\begin{tabular}{|c|c|c|c|c|c|c|}
\hline Treatment & $\begin{array}{l}\text { Day colonies } \\
\text { examined }\end{array}$ & $\begin{array}{l}\text { No. of bees } \\
\text { at start of } \\
\text { each interval }\end{array}$ & $\begin{array}{l}\text { No. and (\%) } \\
\text { bees lost at } \\
\text { each interval }\end{array}$ & $\begin{array}{l}\text { No. and (\%) } \\
\text { bees drifted at } \\
\text { each interval }\end{array}$ & $\begin{array}{l}\text { No. } \\
\text { drifted } \\
\text { west }\end{array}$ & $\begin{array}{l}\text { No. } \\
\text { drifted } \\
\text { east }\end{array}$ \\
\hline A & $\begin{array}{l}1 \\
4 \\
7\end{array}$ & $\begin{array}{l}134.7 \pm 14.4 \\
120.7 \pm 12.5 \\
117.0 \pm 12.5\end{array}$ & $\begin{array}{c}14.0 \pm 3.0(10) \\
3.7 \pm 1.2(3) \\
11.0 \pm 4.4(9)\end{array}$ & $\begin{array}{l}13.7 \pm 0.6(10) \\
18.3 \pm 0.6(15) \\
15.0 \pm 2.0(13)\end{array}$ & $\begin{array}{r}8.3 \pm 1.5 \\
10.7 \pm 0.6 \\
9.3 \pm 1.5\end{array}$ & $\begin{array}{l}5.3 \pm 1.2 \\
7.7 \pm 0.6 \\
5.7 \pm 0.6\end{array}$ \\
\hline B & $\begin{array}{l}1 \\
4 \\
7\end{array}$ & $\begin{array}{r}119.7 \pm 17.5 \\
103.0 \pm 13.5 \\
99.0 \pm 15.1\end{array}$ & $\begin{array}{c}16.7 \pm 4.0(14) \\
4.0 \pm 1.7(4) \\
14.0 \pm 5.6(14)\end{array}$ & $\begin{array}{l}14.7 \pm 0.6(12) \\
19.3 \pm 2.1(19) \\
20.3 \pm 2.1(21)\end{array}$ & $\begin{array}{r}7.7 \pm 1.5 \\
11.7 \pm 0.6 \\
12.7 \pm 2.1\end{array}$ & $\begin{array}{l}7.0 \pm 1.7 \\
7.7 \pm 1.5 \\
7.7 \pm 2.1\end{array}$ \\
\hline C & $\begin{array}{l}1 \\
4 \\
7\end{array}$ & $\begin{array}{r}120.7 \pm 19.0 \\
102.3 \pm 13.1 \\
90.0 \pm 13.7\end{array}$ & $\begin{array}{l}18.3 \pm 6.0(15) \\
12.0 \pm 1.0(12) \\
16.7 \pm 4.5(18)\end{array}$ & $\begin{array}{l}25.3 \pm 5.5(21) \\
33.7 \pm 15.1(33) \\
34.7 \pm 5.1(38)\end{array}$ & $\begin{array}{l}20.7 \pm 7.2 \\
21.7 \pm 8.1 \\
25.3 \pm 6.0\end{array}$ & $\begin{array}{r}4.7 \pm 3.8 \\
12.0 \pm 7.2 \\
9.3 \pm 4.0\end{array}$ \\
\hline
\end{tabular}

* ( $\mathrm{SD}, 3$ reps.) 
within the first day after hiving, and that the loss can continue, but at a lower rate. Bee loss from colonies moved outdoors after winter confinement (Jay and Harris, 1979) can also be high (13-65\%). The difference in loss in our study due to transportation $(B-A)$ and relocation (C-A) was 10 and $23 \%$, respectively. The difference in bee loss among the 3 treatments can be related primarily to the fact that the bees must reorient when being transported and relocated. This is particularly true if transporting results in a change in location. Also, agitation during transportation may account for the $10 \%$ difference in loss compared to the unmoved treatment. Relocation appears to add $13 \%$ more loss compared to the transported treatment.

\section{Drifting of bees}

The number of bees that drifted was greatest during the first day of flight in all treatments. Most of the drift occurred in the relocated colonies (21\%) with lesser amounts in the transported and the unmoved colonies, 12 and $10 \%$, respectively (Table II). The number of bees drifting to neighbouring colonies continued, but at lower levels, for the next two inspections. Drift from unmoved, transported and relocated colonies after 4 days of flight was 15,19 and $33 \%$, respectively, and after 7 days was 13,21 and $38 \%$, respectively. Drift along the row was greater in a westerly direction than in an easterly direction which is similar to studies with package bees (Jay, 1969). This phenomenon was particularly noticeable in the bees from the relocated colonies.

Drifting may cause major problems in commercial apiaries (e.g., Jay, 1970) and should be minimized to maintain uniform strength of colonies. Jay (1969) has shown that drifting in package bees tends to be low during the first day of flight but may increase thereafter. Our results show higher levels during the first day of flight and lower levels thereafter. Because more colonies are being wintered, particularly in western Canada, colonies will likely be moved more often from spring locations to honey producing locations or into crops for pollination. Thus, methods to minimize bee loss and dritting are required. A future paper will discuss orientation cues in relation to this matter.

Table III. Probability ( \pm SE) of bee loss for each treatment-age combination.

Treatment Bee age (days)

$21(1) \quad 24(4) \quad 27(7)$
A
$0.10 \pm 0.015$
$0.03 \pm 0.009$
$0.09 \pm 0.015$
B
$0.14 \pm 0.018$
$0.04 \pm 0.011$
$0.14 \pm 0.020$
C
$0.15 \pm 0.019$
$0.12 \pm 0.018$
$0.18 \pm 0.024$

Treatment designations are the same as for Table II. 


\section{Acknowledgments}

The authors wish to thank L.P. Lefkovitch, Statistican, Agriculture Canada, ESRC, Ottawa, for his advice and D.T. Fairey and D.L. Woods for their comments on the manuscript.

\section{References}

Free J.B. (1958) The drifting of honeybees. J. Agric. Sci. 51, 294-306

Free J.B., Free N.W. \& Jay S.C. (1960) The effect on foraging behavior of moving honeybee colonies to crops before or after flowering has begun. J. Econ. Entomol. 53, 564-566

Free J.B. \& Spencer-Booth Y. (1961) Further experiments on the drifting of honeybees. $J$. Agric. Sci. 57, 153-158

Free J.B. \& Williams I.H. (1974) Influence of the location of honeybee colonies on their choice of pollen sources. J. Appl. Ecol. II, 925935
Harris J.L. (1979) A rapid method for colourmarking single honeybees with fluorescent paint. J. Apic. Res. 18, 201-203

Jay S.C. (1965) Drifting of honeybees in commercial apiaries. I. Effect of various environmental factors. J. Apic. Res. 4, 167-175 Jay S.C. (1968) Drifting of honeybees in commercial apiaries. IV. Further studies of the effect of apiary layout. J. Apic. Res. 7, 37-44

Jay S.C. (1969) Studies on hiving package bees. I. Effects of various factors on loss and drifting of bees. J. Apic. Res. 8, 83-89

Jay S.C. (1970) Studies on hiving package bees. III. Effects of various hiving methods on loss of bees. J. Apic. Res. 9, 71-78

Jay S.C. \& Harris L. (1979) Loss and drifting of honey bees from hives moved outside after indoor wintering. J. Apic. Res. 18, 52-56

McCullagh P. \& Nelder J.A. (1983) In : Generalized linear models. Chapman and Hall, London

Moeller F.E. (1973) Timing of placement of colonies of honeybees for pollination of cranberries. J. Econ. Entomol. 66, 370-372

Todd F.E. \& McGregor S.E. (1960) The use of honey bees in the production of crops. Annu. Rev. Entomol. 5, 265-278 